\title{
Partitioning Carbon Dioxide Emission and Assessing Dissolved Organic Carbon Leaching of a Drained Peatland Cultivated with Pineapple at Saratok, Malaysia
}

\author{
Liza Nuriati Lim Kim Choo ${ }^{1,2}$ and Osumanu Haruna Ahmed \\ ${ }^{1}$ Department of Crop Science, Faculty of Agriculture and Food Science, Universiti Putra Malaysia (UPM), Bintulu Campus, \\ P.O. Box 396,97008 Bintulu, Sarawak, Malaysia \\ ${ }^{2}$ Soil and Water Management Programme, Strategic Resource Research Centre, Malaysian Agricultural Research and \\ Development Institute (MARDI), P.O. Box 59, Roban, 95300 Saratok, Sarawak, Malaysia \\ Correspondence should be addressed to Osumanu Haruna Ahmed; osumanu@upm.edu.my
}

Received 31 May 2014; Revised 8 July 2014; Accepted 28 July 2014; Published 19 August 2014

Academic Editor: Antonio Paz González

Copyright (C) 2014 L. N. Lim Kim Choo and O. H. Ahmed. This is an open access article distributed under the Creative Commons Attribution License, which permits unrestricted use, distribution, and reproduction in any medium, provided the original work is properly cited.

\begin{abstract}
Pineapples (Ananas comosus (L.) Merr.) cultivation on drained peats could affect the release of carbon dioxide $\left(\mathrm{CO}_{2}\right)$ into the atmosphere and also the leaching of dissolved organic carbon (DOC). Carbon dioxide emission needs to be partitioned before deciding on whether cultivated peat is net sink or net source of carbon. Partitioning of $\mathrm{CO}_{2}$ emission into root respiration, microbial respiration, and oxidative peat decomposition was achieved using a lysimeter experiment with three treatments: peat soil cultivated with pineapple, bare peat soil, and bare peat soil fumigated with chloroform. Drainage water leached from cultivated peat and bare peat soil was also analyzed for DOC. On a yearly basis, $\mathrm{CO}_{2}$ emissions were higher under bare peat $\left(218.8 \mathrm{t} \mathrm{CO}_{2}\right.$ ha/yr) than under bare peat treated with chloroform $\left(205 \mathrm{t} \mathrm{CO}_{2} \mathrm{ha} / \mathrm{yr}\right)$, and they were the lowest $\left(179.6 \mathrm{t} \mathrm{CO}_{2} \mathrm{ha} / \mathrm{yr}\right)$ under cultivated peat. Decreasing $\mathrm{CO}_{2}$ emissions under pineapple were attributed to the positive effects of photosynthesis and soil autotrophic activities. An average $235.7 \mathrm{mg} / \mathrm{L}$ loss of DOC under bare peat suggests rapid decline of peat organic carbon through heterotrophic respiration and peat decomposition. Soil $\mathrm{CO}_{2}$ emission depended on moderate temperature fluctuations, but it was not affected by soil moisture.
\end{abstract}

\section{Introduction}

Tropical peat soils are generally defined as soils formed by the accumulation of partially decayed woody plant materials under waterlogged condition. Tropical peatlands cover 27.1 million hectares in Southeast Asia [1] and about 2.6 million hectares in Malaysia [2]. Peats of the tropics are increasingly being cultivated. Although they store large amount of organic carbon, peat soils drained for agriculture in particular accelerate their decomposition rates. Rapid decomposition of peats leads to increase in $\mathrm{CO}_{2}$ release into the atmosphere $[3,4]$. Carbon dioxide may be emitted from peatland through burning by wildfires, microbial respiration, root respiration, and physical oxidation $[5,6]$. Carbon dioxide emissions are related to water table depth [7], soil temperature [8,9], fertilization [10], land use type [11], and peat type [12]. Moreover, carbon in the form of DOC is lost through leaching due to microbial metabolism [13]. Carbon losses through emission and leaching may shift the peatland carbon balance from sink to source [14].

In Malaysia, approximately 600,000 hectares of peatland are cultivated with oil palm, pineapple, rubber, and sago [15]. Presently, there is scarce information on soil $\mathrm{CO}_{2}$ emission from pineapple cultivation on drained peat soils. The understanding of the contribution of pineapple cultivation on peats to the greenhouse gas emission is important, as $90 \%$ of pineapples are grown on peat soils of Malaysia [16]. Although attempts have been made to measure $\mathrm{CO}_{2}$ emission from cultivated tropical peats, such studies are limited to a few measurements. The recent measurements only account for total soil $\mathrm{CO}_{2}$ emission as they do not partition soil respiration into root respiration, microbial respiration, and oxidative 
peat decomposition $[10,17]$. With the growing concern about the effects of greenhouse gases on the environmental quality coupled with the need to achieve sustainable agriculture, it is essential to partition $\mathrm{CO}_{2}$ emission before deciding on whether cultivated or degraded soils are net sinks or net sources of atmospheric greenhouse gases [5]. Accounting for $\mathrm{CO}_{2}$ emission from cultivated peats is needed to evaluate future rates of increase in atmospheric greenhouse gases and their effect on the global environmental change processes $[18,19]$.

Based on the above rationale, the general objective of this study was to quantify $\mathrm{CO}_{2}$ emission and also carbon loss from a drained tropical peat grown with pineapple. The first specific objective was to partition soil $\mathrm{CO}_{2}$ emission from a cultivated peat into root respiration, microbial respiration, and oxidative peat decomposition. The second specific objective was to estimate DOC in water drained from lysimeters with peat soil. The third specific objective was to assess the effects of soil temperature and soil moisture on soil $\mathrm{CO}_{2}$ emission.

In this study, it was hypothesized that microbial respiration and peat decomposition will cause higher loss of $\mathrm{CO}_{2}$ and DOC from the bare peat soil than from the peat soil cultivated with pineapple. This hypothesis is based on the assumption that $\mathrm{CO}_{2}$ emission of drained and uncultivated peats is mainly controlled by heterotrophic respiration. However, $\mathrm{CO}_{2}$ and DOC release in the presence of root respiration (cultivated peats) is expected to be lower as both processes are regulated by autotrophic respiration and photosynthesis. Information obtained from partitioning respiration components could be used to control $\mathrm{CO}_{2}$ and DOC losses from drained tropical peats that are cultivated with pineapples and other related crops.

\section{Materials and Methods}

2.1. Site Description. The study was carried out at the Malaysian Agricultural Research and Development Institute (MARDI) Peat Research Station at Saratok, Sarawak, Malaysia. The research station has a total area of 387 hectares located on a logged-over forest with a flat topography of 5 to $6 \mathrm{~m}$ above mean sea level. Based on the Von Post Scale of $\mathrm{H7}$ to $\mathrm{H} 9$, the peat soil is classified as well decomposed dark brown to almost dark coloured sapric peat with a strong smell. The thickness of the peat soil ranges from 0.5 to $3.0 \mathrm{~m}$.

The mean temperature of the peat area ranges from 22.1 to $31.7^{\circ} \mathrm{C}$. The relative humidity of the area ranges from 61 to $98 \%$. The annual mean rainfall of the area is $3749 \mathrm{~mm}$. In the wet season (November to January), the monthly rainfall is more than $400 \mathrm{~mm}$ whereas in the dry season, particularly in July, the mean rainfall is $189 \mathrm{~mm}$.

2.2. Soil Chemical and Physical Analysis. Before setting up the lysimeter experiment, peat samples were collected at a peat excavation site ( 0.5 hectares) located at MARDI Peat Research Station. The experimental area was planted with Moris pineapple from 2004 to 2005, after which it was abandoned to lie fallow for six years. Samplings were performed at depths of $0-20 \mathrm{~cm}, 20-40 \mathrm{~cm}$, and $40-, 60 \mathrm{~cm}$ systematically in 12 points located over a $20 \mathrm{~m} \times 12.5 \mathrm{~m}$ grid. The soil samples were analyzed for $\mathrm{pH}$, conductivity, ammonium- $\mathrm{N}$, nitrate- $\mathrm{N}$, organic carbon, total nitrogen, and cation exchange capacity (CEC). Soil $\mathrm{pH}$ and conductivity were measured based on a $1: 5$ soil to water suspension [20]. Ammonium-N and nitrate$\mathrm{N}$ were determined using the steam distillation method [21]. Soil organic carbon was determined using the Walkley and Black method [22] whereas total nitrogen was determined using the Kjeldahl method [23]. Cation exchange capacity was determined using the Harada and Inoko method [24]. Bulk density was determined using the core method [25], and soil water holding capacity was determined using the method of Dugan et al. [26].

2.3. Characteristics of the Lysimeters. Twelve cylindrical field lysimeters made from high density polyethylene, measuring $1.43 \mathrm{~m}$ in diameter and $1.58 \mathrm{~m}$ in height, were set up in April 2012 to mimic the natural condition of drained tropical peats. The size of the lysimeters used in this study was designed to ensure satisfactory growth and development of the pineapples for sixteen months. The twelve lysimeters were used for three peat soil treatments (Section 2.4). The lysimeters were equipped with water spillage opening which was attached to clear tubes mounted on the outside of the vessel to regulate and monitor water level.

Each lysimeter was filled with peat soil up to $120 \mathrm{~cm}$ depth. Water loss from the soil was replenished by showering each lysimeter with 34.5 litres of rainwater. The amount of rainwater added was based on the volume of the fabricated lysimeter and the mean annual rainfall at Saratok, Sarawak, Malaysia. The lysimeters with the peat soil were left in the open for five months to ensure that the peat soil had settled before beginning this study. The length of this initial phase was based on weekly determination of the peat subsidence. The equilibrium state was achieved in September 2012 before carrying out the $\mathrm{CO}_{2}$ measurement. Water table of the peat was maintained at 50 to $60 \mathrm{~cm}$ from the soil surface throughout the duration of the experiment.

2.4. Peat Soil Treatments. The three treatments involved in this lysimeter experiment were peat soil cultivated with pineapple (A), bare peat soil (B), and bare peat soil treated with chloroform $(\mathrm{C})$. Each treatment had four replications. The treatments were arranged in completely randomized design.

Treatment $\mathrm{A}$ represents total amount of $\mathrm{CO}_{2}$ emitted from root respiration, microbial respiration, and peat decomposition. Three Moris pineapple suckers were planted in the lysimeters at a distance of $30 \mathrm{~cm}$. Treatment $\mathrm{B}$ represents $\mathrm{CO}_{2}$ emitted by microbial respiration and peat decomposition. Weed sprouting on the soil surface was controlled when necessary. Treatment $\mathrm{C}$ represents $\mathrm{CO}_{2}$ emitted by oxidative peat decomposition. For this treatment, concentrated chloroform was applied evenly on the peat soil surface to eliminate microbial respiration, and 64.6 litres of concentrated chloroform was used. This volume was based on the peat soil's water holding capacity. After the chloroform application, the soil was covered with cling film and canvas to produce 
TABle 1: Physical and chemical properties of a drained peat soil sampled at different depths.

\begin{tabular}{|c|c|c|c|c|c|}
\hline \multirow{2}{*}{ Variable } & \multirow{2}{*}{ Mean $(0$ to $10 \mathrm{~cm})$} & \multicolumn{3}{|c|}{ Results per soil depth $(\mathrm{cm})$} & \multirow{2}{*}{ Reported standard range } \\
\hline & & 0 to $20 \mathrm{~cm}$ & 20 to $40 \mathrm{~cm}$ & 40 to $60 \mathrm{~cm}$ & \\
\hline \multicolumn{6}{|c|}{ Physical properties } \\
\hline Bulk density $\left(\mathrm{g} / \mathrm{cm}^{3}\right)$ & 0.14 & & & & $0.09-0.12[31]$ \\
\hline Water holding capacity (\%) & 40.2 & & & & $275-322[31]$ \\
\hline Moisture (\%) & & $80.9^{c}$ & $84.9^{\mathrm{b}}$ & $88.8^{\mathrm{a}}$ & $90-95[32]$ \\
\hline \multicolumn{6}{|c|}{ Chemical properties } \\
\hline $\mathrm{pH}$ & & $3.8^{\mathrm{a}} \pm 0.1$ & $3.9^{\mathrm{a}} \pm 0.1$ & $3.9^{\mathrm{a}} \pm 0.1$ & $3.0-4.5[31]$ \\
\hline Conductivity $(\mu \mathrm{S} / \mathrm{cm})$ & & $178.5^{\mathrm{a}} \pm 4.6$ & $175.4^{\mathrm{a}} \pm 4.3$ & $172.7^{\mathrm{a}} \pm 2.4$ & $<200[33]$ \\
\hline Cation exchange capacity $\left(\mathrm{cmol}_{(+)} / \mathrm{kg}\right)$ & & $146.4^{\mathrm{a}} \pm 20.1$ & $137.6^{\mathrm{a}} \pm 13.7$ & $175.6^{\mathrm{a}} \pm 34.9$ & $\begin{array}{l}200[31] \\
145[33]\end{array}$ \\
\hline Total organic carbon $(\%)$ & & $40.0^{\mathrm{a}} \pm 0.8$ & $39.8^{\mathrm{a}} \pm 1.4$ & $36.5^{\mathrm{a}} \pm 1.1$ & $\begin{array}{c}12-60[31] \\
20.4-38.4[34]\end{array}$ \\
\hline Total nitrogen (\%) & & $1.33^{\mathrm{a}} \pm 0.03$ & $1.18^{\mathrm{b}} \pm 0.04$ & $1.12^{\mathrm{b}} \pm 0.03$ & $1.10-1.67[32]$ \\
\hline Ammonium-Nitrogen (mg/L) & & $138.5^{\mathrm{a}} \pm 16.2$ & $100.0^{\mathrm{b}} \pm 4.2$ & $94.8^{\mathrm{b}} \pm 7.7$ & n.a. \\
\hline Nitrate-Nitrogen (mg/L) & & $72.0^{\mathrm{a}} \pm 5.4$ & $48.8^{\mathrm{b}} \pm 6.3$ & $65.8^{\mathrm{ab}} \pm 3.0$ & n.a. \\
\hline
\end{tabular}

Values (mean \pm standard error) with different letters across the column are significantly different at $P \leq 0.05$.

(Note: n.a.: not available).

a vacuum-like condition in the lysimeters to minimize chloroform volatilization. The soil microbial population before and after the chloroform application was determined using the culture method. With this method, bacteria, fungi, and actinomycetes were enumerated as colony forming units (CFU) per gram of fresh soil on nutrient agar, Rose Bengal, and actinomycetes isolation agar, respectively [27]. The concentrated chloroform was used to fumigate the peat soil one week before the soil $\mathrm{CO}_{2}$ measurement was commenced (optimum time interval achieved for the biocidal effect on soil microorganisms).

2.5. Soil $\mathrm{CO}_{2}$ Emission Measurements. Carbon dioxide emissions from the field lysimeters were measured using the closed chamber method [28]. Extracted gas samples from the chamber were analyzed for $\mathrm{CO}_{2}$ using gas chromatography (Agilent 7890A) equipped with thermal conductivity detector (TCD). The $\mathrm{CO}_{2}$ results were based on the measured $\mathrm{CO}_{2}$ from treatments $\mathrm{A}, \mathrm{B}$, and $\mathrm{C}$ in the wet and dry seasons. The values were averaged and converted into units of $\mathrm{t} / \mathrm{ha} / \mathrm{yr}$. The gas flux was calculated from the increase in the chamber concentration over time using the chamber volume and soil area covered, using the following equation [28-30]:

$$
\text { Flux }=\left[\frac{d\left(\mathrm{CO}_{2}\right)}{d t}\right] \times \frac{P V}{A R T},
$$

where $d\left(\mathrm{CO}_{2}\right) /(d t)$ is the evolution rate of $\mathrm{CO}_{2}$ within the chamber headspace at a given time after putting the chamber into the soil, $P$ is the atmospheric pressure, $V$ is the volume headspace gas within the chamber, $A$ is the area of soil enclosed by the chamber, $R$ is the gas constant, and $T$ is the air temperature.

The gas flux was measured in the early morning (2.40 a.m. to 5.55 a.m.), morning (7.15 a.m. to 10.30 a.m.), mid-morning to afternoon (10.35 a.m. to 1.50 p.m.), afternoon (1.55 p.m. to 5.10 p.m.), evening ( 8.00 p.m. to 11.15 p.m.), and night (11.20 p.m. to 2.35 a.m.) to obtain a 24 hour $\mathrm{CO}_{2}$ emission. The flux measurements were carried out in September 2012, November 2012, and January 2013 to represent the concentrations of $\mathrm{CO}_{2}$ in the wet season whereas April 2013 and July 2013 flux measurements represent the concentrations of $\mathrm{CO}_{2}$ in the dry season. Soil temperature and moisture were measured using Eijkelkamp IP68 and ML3 sensors, respectively. Rainfall, temperature, and air humidity data were also recorded using a portable weather station (WatchDog 2900) installed at the experimental site.

2.6. Measurement of DOC. Water draining through the openings of the lysimeters of treatments $A$ and $B$ was collected for determinations of DOC concentration. The water samples were chilled at $10^{\circ} \mathrm{C}$ before being analyzed. The samples were filtered to pass a $0.45 \mu \mathrm{m}$ cellulose nitrate membrane filter and the contents of DOC were determined using total carbon analyzer (Shimadzu TOC). The DOC from treatment $\mathrm{C}$ was not measured because of the high residual chloroform in the peat water.

2.7. Statistical Analysis. Treatment effects were tested using analysis of variance (ANOVA) and means of treatments were compared using Duncan's New Multiple Range Test at $P \leq$ 0.05. The relationships between gas flux, soil temperature, and soil moisture were analyzed using Pearson correlation analysis. The statistical software used for this analysis was the Statistical Analysis System (SAS) Version 9.3.

\section{Results and Discussion}

3.1. Peat Physical Properties. Results of peat soil properties are compared with the previously reported ranges (Table 1) 
for tropical peats in Southeast Asia [31] and Malaysia [3133]. The bulk density of the sampled peat soil is within the reported range [31] whereas the water holding capacity and moisture content of the soil are lower than the reported range $[31,32]$. The bulk density at $10 \mathrm{~cm}$ ranged from 0.09 to $0.18 \mathrm{~g} / \mathrm{cm}^{3}$, which is typical of a sapric peat. The bulk density was determined at $10 \mathrm{~cm}$ due to the saturated condition of the excavation site. The water holding capacity of the peat $(40.2 \%)$ was below the reported range [31] because the water holding capacity determination was based on oven-dry weight method [31]. The increasing moisture content with increasing peat soil depth is related to the high water table at the excavation site during soil sampling. However, the soil moisture is lower than the reported range [32]. Removal of trees and debris after land clearing may have accelerated oxidative peat decomposition and therefore soil moisture content is lower.

3.2. Peat Chemical Properties. Values of $\mathrm{pH}$, conductivity, CEC, total organic carbon, and total nitrogen of the peat soil studied here are within the reported range [31-34] for the peat soil at MARDI Peat Research Station (Table 1). The soil chemical properties showed no significant difference with depth except for total nitrogen, ammonium-N, and nitrate$\mathrm{N}$. The $\mathrm{pH}$ of the peat soil was low, suggesting a need for liming before being cultivated. The low conductivity of the peat soil also indicates that the soil is not saline as the research station is drained by two large tidal rivers (Sebelak River and Nyabor River). However, intrusion of salt water at the station is prevented by a tidal gate constructed at the main outlet drain leading to Nyabor River. The CEC of the peat soil is high because of lignin-derivatives formed during decomposition. Ion exchange in peats relates to carboxyl and phenolic radicals of humic substances and hemicelluloses [31]. However, the CEC obtained is higher than the reported range [33]. This may be attributed to the past liming activities at the excavation site as this area was cultivated with pineapples from 2004 to 2005. The total organic carbon of the soil is within the reported range [31, 34]. The high organic carbon content can be associated with the botanical origin (woody) of the sapric peat used in this study $[31,32]$. The total nitrogen of the soil was high and it was mostly in organic form. The total nitrogen ranged from 1.1 to $1.3 \%$. Ammonium-N ranged from 94.8 to $138.5 \mathrm{mg} / \mathrm{L}$ whereas nitrate- $\mathrm{N}$ ranged from 48.8 to $72.0 \mathrm{mg} / \mathrm{L}$ at the three soil depths. Total nitrogen, ammonium-N, and nitrate$\mathrm{N}$ contents decreased with increasing soil depth (from 0$20 \mathrm{~cm}$ to $20-40 \mathrm{~cm}$ depths) because decomposition of peats generally decreases (low oxidation with increasing water content) down the soil profile [31].

3.3. Soil $\mathrm{CO}_{2}$ Emission. The $\mathrm{CO}_{2}$ emissions under treatments $\mathrm{A}, \mathrm{B}$, and $\mathrm{C}$ varied in the wet and dry seasons (Figure 1). In the wet season, the $\mathrm{CO}_{2}$ emission under treatment $\mathrm{A}$ was significantly lower than under treatments $\mathrm{B}$ and $\mathrm{C}$. However, in the dry season, the $\mathrm{CO}_{2}$ emission under treatment $\mathrm{C}$ was significantly lower than under treatments $\mathrm{A}$ and $\mathrm{B}$. The $\mathrm{CO}_{2}$

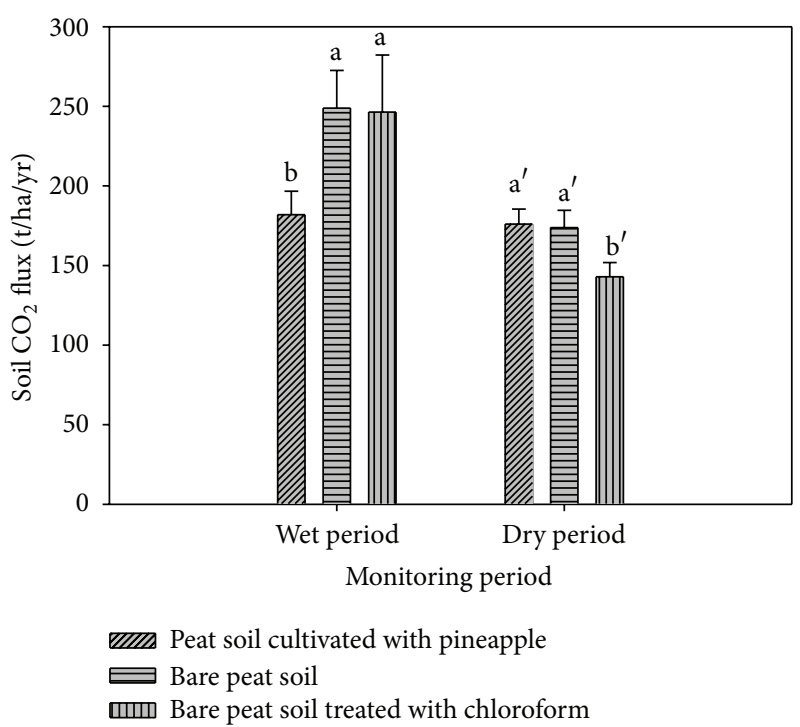

Figure 1: Carbon dioxide emission (wet and dry seasons) from peat soil cultivated with pineapple, bare peat soil, and chloroform fumigated peat soil. (Error bars represent standard error and soil mean fluxes with different letters are significantly different at $P \leq$ 0.05.)

emission under treatment A was affected by root development and growth of the pineapple plants. Differences in day and night temperatures in the wet and dry seasons (Table 2) may have also impeded photosynthetic activity of the pineapple plants [35]. Furthermore, heterotrophic respiration and decomposition of root exudates in the rhizosphere $[5,36]$ may have contributed to the $\mathrm{CO}_{2}$ emission under treatment $\mathrm{A}$.

The $\mathrm{CO}_{2}$ emission under treatment $\mathrm{B}$ is related to the microbial population of the peat soil and the availability of adequate substrate for microbial metabolism, but not to plant root activities $[5,12]$. The $\mathrm{CO}_{2}$ emission under treatment $\mathrm{B}$ was also regulated by moderate temperature fluctuation (Table 2), which is in agreement with previous studies in peat soils $[9,12]$. The effect of soil temperature on $\mathrm{CO}_{2}$ emission from peat soils has been also recently studied by Jauhiainen et al. [8] and Paz-Ferreiro et al. [37], showing that the rate of organic material decomposition increased with increasing temperature of peat soils.

The $\mathrm{CO}_{2}$ emission under treatment $\mathrm{C}$ was mainly due to oxidative peat decomposition (shrinkage and consolidation) as the fumigant (chloroform) used inhibited microbial respiration. Bacteria and actinomycetes populations before and after fumigation were statistically similar. Fungi were not detected in this present study. These findings are in agreement with most previous findings, which demonstrate that chloroform can effectively kill (94\% to 99\%) microorganisms [3842]. The effectiveness of the fumigation is supported by the decrease in the mean soil microbial biomass carbon (Table 3). This result also corroborates previous work by Zelles et al. [43] who reported $80 \%$ reduction in microbial biomass carbon after fumigating a soil with chloroform. The fact that the subsidence rates of the peat soil in treatments A, B, and $\mathrm{C}$ were statistically similar suggests that the chloroform used 
TABle 2: Day and night temperatures of the experimental site (Saratok, Malaysia).

\begin{tabular}{|c|c|c|c|c|c|}
\hline \multirow{2}{*}{ Variable } & \multicolumn{3}{|c|}{ Wet season } & \multicolumn{2}{|c|}{ Dry season } \\
\hline & September 2012 & November 2012 & January 2013 & April 2013 & July 2013 \\
\hline Mean day time temperature $\left({ }^{\circ} \mathrm{C}\right)$ & 26.7 & 29.2 & 29.6 & 26.3 & 27.0 \\
\hline Mean night time temperature $\left({ }^{\circ} \mathrm{C}\right)$ & 23.6 & 24.9 & 24.5 & 24.6 & 24.7 \\
\hline Mean day and night time temperature differences $\left({ }^{\circ} \mathrm{C}\right)$ & 3.1 & 4.3 & 5.1 & 1.7 & 2.3 \\
\hline \multicolumn{6}{|c|}{ Mean soil temperature $\left({ }^{\circ} \mathrm{C}\right)$} \\
\hline Early morning & $29.8^{\mathrm{a}}$ & $30.0^{\mathrm{bc}}$ & $28.2^{\mathrm{bc}}$ & $30.1^{\mathrm{a}}$ & $28.7^{\mathrm{b}}$ \\
\hline Morning & $30.8^{\mathrm{a}}$ & $32.1^{\mathrm{ab}}$ & $29.8^{\mathrm{a}}$ & $30.5^{\mathrm{a}}$ & $29.5^{\mathrm{b}}$ \\
\hline Mid-morning to afternoon & $30.9^{\mathrm{a}}$ & $32.8^{\mathrm{a}}$ & $30.7^{\mathrm{a}}$ & $30.5^{\mathrm{a}}$ & $30.6^{\mathrm{b}}$ \\
\hline Afternoon & $29.7^{\mathrm{a}}$ & $31.1^{\mathrm{abc}}$ & $30.5^{\mathrm{a}}$ & $29.3^{\mathrm{ab}}$ & $32.6^{\mathrm{a}}$ \\
\hline Evening & $29.5^{\mathrm{a}}$ & $30.1^{\mathrm{bc}}$ & $29.4^{\mathrm{ab}}$ & $28.7^{\mathrm{ab}}$ & $29.2^{\mathrm{b}}$ \\
\hline Night & $29.0^{\mathrm{a}}$ & $29.2^{\mathrm{c}}$ & $27.9^{c}$ & $27.7^{\mathrm{b}}$ & $28.7^{\mathrm{b}}$ \\
\hline
\end{tabular}

Mean values with different letters within the same column are significantly different at $P \leq 0.05$.

TABLE 3: Effect of fumigating drained peat soil with chloroform on soil microbial biomass carbon.

\begin{tabular}{lc}
\hline Monitoring cycle & $\begin{array}{c}\text { Mean soil microbial biomass } \\
\text { carbon } \\
(\mu \mathrm{g} \mathrm{C} / \mathrm{g} \text { soil })\end{array}$ \\
\hline Initial before chloroform & $94.7^{\mathrm{a}}$ \\
application & $29.6^{\mathrm{f}}$ \\
September 2012 & $73.4^{\mathrm{b}}$ \\
November 2012 & $56.0^{\mathrm{d}}$ \\
January 2013 & $67.2^{\mathrm{c}}$ \\
April 2013 & $46.0^{\mathrm{e}}$ \\
\hline July 2013 &
\end{tabular}

Mean values with different letters are significantly different at $P \leq 0.05$.

did not affect $\mathrm{CO}_{2}$ emission due to oxidative peat decomposition. This observation corroborates that of Toyota et al. [40] who also found no significant effect of chloroform fumigation on soil bulk density and compaction. The higher $\mathrm{CO}_{2}$ emission under treatment $\mathrm{C}$ in the wet season was due to the decomposition of dead microorganisms [42]. In contrast, the decrease in the $\mathrm{CO}_{2}$ emission under treatment $\mathrm{C}$ in the dry season was because of the adaptation of the microorganisms towards the biocidal effect of chloroform. Again, it must be stressed that the $\mathrm{CO}_{2}$ emission was mainly because of oxidative peat decomposition $[1,6]$. The oxidative peat decomposition (shrinkage and consolidation) was due to the loss of water in the aerobic layer of the peat. Oxidative peat decomposition is a continuous process and it takes several years to achieve the equilibrium state of peat subsidence.

The $\mathrm{CO}_{2}$ emission was also affected by time of sampling (Figure 2). In the wet season, the $\mathrm{CO}_{2}$ emission decreased from morning to mid-morning to afternoon followed by an increase in the evening. In the dry season, the $\mathrm{CO}_{2}$ emission decreased from the early morning to mid-morning to afternoon followed by an increase in the evening and night. These observations are consistent with the significant negative correlation between soil $\mathrm{CO}_{2}$ emission and soil temperature (Table 4). These findings also suggest that the $\mathrm{CO}_{2}$ emission increased with decreasing temperature. Although the $\mathrm{CO}_{2}$

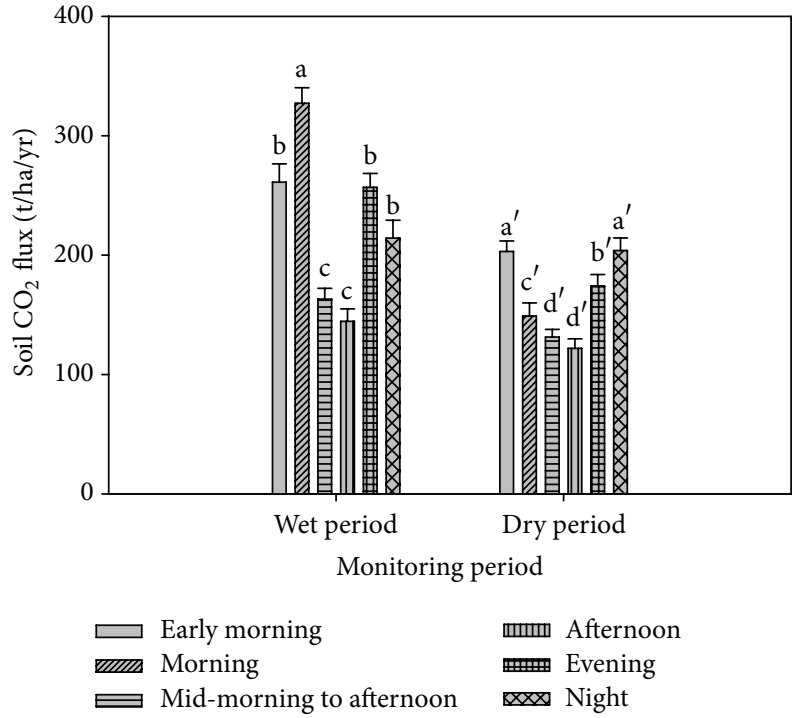

FIGURE 2: Carbon dioxide emission (at different times of the day and different seasons) from peat soil cultivated with pineapple. (Error bars represent standard error and soil mean fluxes with different letters are significantly different at $P \leq 0.05$.)

emission was negatively correlated with soil temperature, the overall data (wet and dry seasons) showed no correlation between $\mathrm{CO}_{2}$ emission and soil temperature (Table 4). This indicates that although soil temperature regulates soil $\mathrm{CO}_{2}$ emission, the differences in the $\mathrm{CO}_{2}$ emissions under treatments $\mathrm{A}, \mathrm{B}$, and $\mathrm{C}$ across time rather depends on the moderate fluctuation in soil temperature $\left(0.2\right.$ and $\left.1.6^{\circ} \mathrm{C}\right)$ of the tropics. There was no correlation between $\mathrm{CO}_{2}$ emission and soil moisture (Table 4 ) because the water table in the lysimeters was maintained at 50 and $60 \mathrm{~cm}$. This finding is further supported by the fact that the soil moisture was not significantly affected by time of sampling (Table 5). In a related study, Kechavarzi et al. [12] found that soil moisture had no effect on $\mathrm{CO}_{2}$ emission in humified peat surface but higher soil moisture which constrained oxygen diffusion affected soil respiration. 
TABLE 4: The relationship between soil $\mathrm{CO}_{2}$ emission, soil temperature, and soil moisture in dry and wet seasons.

\begin{tabular}{|c|c|c|c|c|}
\hline Weather season & Monitoring period & Variable & Soil temperature & Soil moisture \\
\hline \multirow{2}{*}{ Wet season } & September 2012 & & $\begin{array}{l}r=0.2253 \\
P=0.1464\end{array}$ & $\begin{array}{l}r=0.1955 \\
P=0.2091\end{array}$ \\
\hline & November 2012 & & $\begin{array}{r}r=-0.5169 \\
P=0.0001\end{array}$ & $\begin{aligned} r & =0.1127 \\
P & =0.4264\end{aligned}$ \\
\hline \multirow{3}{*}{ Dry season } & January 2013 & Soil $\mathrm{CO}_{2}$ emission & $\begin{array}{r}r=-0.4829 \\
P=0.0004\end{array}$ & $\begin{array}{l}r=0.2290 \\
P=0.1135\end{array}$ \\
\hline & April 2013 & & $\begin{array}{r}r=-0.7431 \\
P=0.0001\end{array}$ & $\begin{array}{c}r=-0.0776 \\
P=0.5558\end{array}$ \\
\hline & July 2013 & & $\begin{array}{c}r=-0.5992 \\
P=0.0001\end{array}$ & $\begin{array}{c}r=-0.2299 \\
P=0.0854\end{array}$ \\
\hline \multicolumn{2}{|c|}{ Pooling data throughout the wet and dry seasons } & & $\begin{array}{l}r=-0.1119 \\
P=0.0710\end{array}$ & $\begin{array}{l}r=0.1027 \\
P=0.0980\end{array}$ \\
\hline
\end{tabular}

Note: top values represent Pearson's correlation coefficient $(r)$ while bottom values represent probability level at $0.05(n=72$ for each monitoring period, $n=$ 360 for pooling data throughout wet and dry seasons).

TABLE 5: Soil moisture during $\mathrm{CO}_{2}$ measurement at different times of the day in dry and wet seasons.

\begin{tabular}{|c|c|c|c|c|c|}
\hline \multirow{3}{*}{ Time } & \multicolumn{3}{|c|}{ Wet season } & \multicolumn{2}{|c|}{ Dry season } \\
\hline & September 2012 & November 2012 & January 2013 & April 2013 & July 2013 \\
\hline & \multicolumn{5}{|c|}{ Mean soil moisture (\%) } \\
\hline Early morning & $77.7^{\mathrm{a}}$ & $76.7^{\mathrm{a}}$ & $77.7^{\mathrm{a}}$ & $77.3^{\mathrm{a}}$ & $75.1^{\mathrm{a}}$ \\
\hline Morning & $80.4^{\mathrm{a}}$ & $77.4^{\mathrm{a}}$ & $78.7^{\mathrm{a}}$ & $77.9^{\mathrm{a}}$ & $75.5^{\mathrm{a}}$ \\
\hline Mid-morning to afternoon & $77.2^{\mathrm{a}}$ & $78.3^{\mathrm{a}}$ & $78.3^{\mathrm{a}}$ & $78.0^{\mathrm{a}}$ & $75.1^{\mathrm{a}}$ \\
\hline Afternoon & $76.2^{\mathrm{a}}$ & $79.7^{\mathrm{a}}$ & $77.5^{\mathrm{a}}$ & $77.5^{\mathrm{a}}$ & $76.7^{\mathrm{a}}$ \\
\hline Evening & $78.5^{\mathrm{a}}$ & $77.6^{\mathrm{a}}$ & $77.0^{\mathrm{a}}$ & $78.4^{\mathrm{a}}$ & $73.6^{\mathrm{a}}$ \\
\hline Night & $76.3^{\mathrm{a}}$ & $77.9^{\mathrm{a}}$ & $76.3^{\mathrm{a}}$ & $78.1^{\mathrm{a}}$ & $76.1^{\mathrm{a}}$ \\
\hline
\end{tabular}

Mean values with same letter within the same column are not significantly different at $P \geq 0.05$.

In summary, the $\mathrm{CO}_{2}$ emission was estimated at about $218.8 \mathrm{t} \mathrm{CO}_{2} \mathrm{ha} / \mathrm{yr}$ under bare peat soil (B), followed by $205 \mathrm{t}$ $\mathrm{CO}_{2} \mathrm{ha} / \mathrm{yr}$ under bare peat soil treated with chloroform $(\mathrm{C})$, and $179.6 \mathrm{t} \mathrm{CO}_{2} \mathrm{ha} / \mathrm{yr}$ under peat soil cultivated with pineapple (A). The higher $\mathrm{CO}_{2}$ emission from treatment $\mathrm{B}$ suggests that it is controlled by heterotrophic respiration whereas the lower $\mathrm{CO}_{2}$ emission from treatment $\mathrm{A}$ suggests that it is regulated by autotrophic respiration (through photosynthetic activity and respiration in the rhizosphere). The $\mathrm{CO}_{2}$ emission in this study was higher than that reported by Jauhiainen et al. [8], who found that microbial respiration contributed with $80 \mathrm{t} \mathrm{CO}$ ha/yr whereas root respiration contributed with $21 \%$ of the total respiration. The $\mathrm{CO}_{2}$ emission rate reported in this study is not consistent with that of Jauhiainen et al. [8] because the present study was carried out on sapric peat whereas that reported by Jauhiainen et al. [8] was on fibric to hemic peat.

3.4. Dissolved Organic Carbon. The DOC under the bare peat soil (B) $(235.7 \mathrm{mg} / \mathrm{L})$ was significantly higher than under peat soil cultivated with pineapple (A) (194.6 mg/L) (Figure 3) because of the greater decomposition of organic substrate by heterotrophs. One of the byproducts of heterotrophs is DOC [13]. The lower DOC under treatment A is related to the consumption of carbon, nitrogen, and root exudates by microbes at the rhizosphere $[5,44]$. The DOC under treatment B is

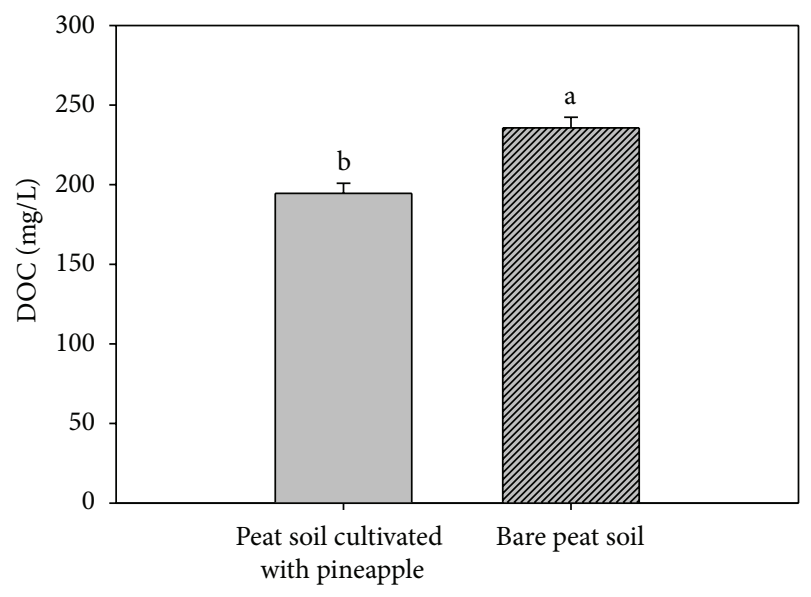

FIGURE 3: Dissolved organic carbon (DOC) leaching losses under peat soil cultivated with pineapple and bare peat soil. (Error bars represent standard error, and mean DOC with different letters are significantly different at $P \leq 0.05$.)

in accordance with the results of our field monitoring as the mean $\mathrm{CO}_{2}$ under treatment $\mathrm{B}\left(218.8 \mathrm{t} \mathrm{CO}_{2}\right.$ ha/yr) was higher than under treatment $\mathrm{A}\left(179.6 \mathrm{t} \mathrm{CO}_{2} \mathrm{ha} / \mathrm{yr}\right)$.

The DOC was statistically similar irrespective of the monitoring period (Figure 4). This result was expected as 


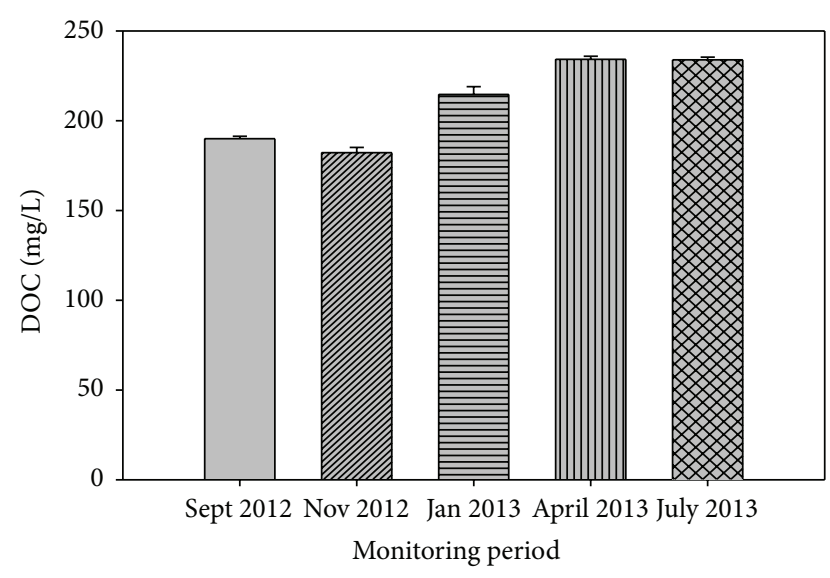

FIGURE 4: Dissolved organic carbon from peat soil cultivated with pineapple in the wet and dry seasons. (Error bars represent standard error and mean DOC are not significantly different at $P \geq 0.05$.)

the peat water table was controlled to fluctuate between 50 and $60 \mathrm{~cm}$ in the lysimeters, so as to minimize oxygen availability for carbon decomposition in the aerobic zone. Furthermore, the restriction of soil water movement in the lysimeter may have contributed to the similarity of the DOC content. This finding is also consistent with the fact that wet and dry seasons have no significant effect on DOC production in drained peats.

The higher DOC in this study than the initial concentration $(64.3 \mathrm{mg} / \mathrm{L})$ suggests that draining peat soils accelerates their chemical oxidation. This buttresses the fact that carbon is not only lost as $\mathrm{CO}_{2}$ but also lost through DOC. Loss of DOC is an important indicator for carbon release, because when it is leached from the peat soils into rivers it poses environmental pollution risk. This is because DOC can react with chlorine to form trihalomethane and haloacetic acids. Although these chemicals are carcinogenic, they are not completely removed from treated water $[45,46]$.

\section{Conclusion}

Peat soils drained for agriculture released $218.8 \mathrm{t} \mathrm{CO}_{2} \mathrm{ha} / \mathrm{yr}$ under bare conditions, followed by bare peat soil treated with chloroform (205 $\left.\mathrm{t} \mathrm{CO}_{2} \mathrm{ha} / \mathrm{yr}\right)$, and peat soil cultivated with pineapple (179.6 t $\mathrm{CO}_{2} \mathrm{ha} / \mathrm{yr}$ ). The lower $\mathrm{CO}_{2}$ emission from the peat soil cultivated with pineapple was due to the regulation by pineapple photosynthetic activity, heterotrophic respiration, and decomposition of root exudates at the rhizosphere whereas the $\mathrm{CO}_{2}$ emission from the bare peat fumigated with chloroform was mainly due to shrinkage and consolidation of the soil. Soil $\mathrm{CO}_{2}$ emission was neither affected by soil temperature nor by soil moisture but the emission seemed to be controlled by moderate soil temperature fluctuation in the wet and dry seasons. Draining peat soil affected leaching of DOC. An average $235.7 \mathrm{mg} / \mathrm{L}$ loss of DOC under bare conditions, arisen principally from microbial respiration and oxidative peat decomposition, suggests rapid decline of peat organic matter through heterotrophic microbial activities. Identification of beneficial microorganisms that reduce peat decomposition may help to minimize carbon dioxide emission from cultivated peats. Further research is needed to assess partitioning of soil $\mathrm{CO}_{2}$ emission at the rhizosphere, as $\mathrm{CO}_{2}$ emission from drained peats seems to be influenced by heterotrophic and autotrophic respiration processes.

\section{Conflict of Interests}

The authors declare that there is no conflict of interests regarding the publication of this paper.

\section{Acknowledgments}

The authors acknowledge the financial support of the Ministry of Education Malaysia through Universiti Putra Malaysia. This research was funded through Research University Grants Scheme (RUGS). The facilities provided by the Malaysian Agricultural Research and Development Institute at MARDI Saratok Peat Research Station for this study are appreciated.

\section{References}

[1] A. Hooijer, S. Page, J. G. Canadell et al., "Current and future $\mathrm{CO}_{2}$ emissions from drained peatlands in Southeast Asia," Biogeosciences, vol. 7, no. 5, pp. 1505-1514, 2010.

[2] A. B. Ismail and J. Jamaludin, "Land clearing techniques employed at MARDI Peat Research Station, Sessang, Sarawak, and their immediate impacts," in A Case Study at MARDI Peat Research Station Sessang, Sarawak, Malaysia, A.B. Ismail, H.K. Ong, M.J. Mohamad Hanif, and M.S. Umi Kalsom, Eds., pp. 1-8, MARDI, Sarawak, Malaysia, 2007.

[3] M. Maljanen, V. M. Komulainen, J. Hytönen, P. J. Martikainen, and J. Laine, "Carbon dioxide, nitrous oxide and methane dynamics in boreal organic agricultural soils with different soil characteristics," Soil Biology and Biochemistry, vol. 36, no. 11, pp. 1801-1808, 2004.

[4] B. Kløve, T. E. Sveistrup, and A. Hauge, "Leaching of nutrients and emission of greenhouse gases from peatland cultivation at Bodin, Northern Norway," Geoderma, vol. 154, no. 3-4, pp. 219$232,2010$.

[5] Y. Kuzyakov, "Sources of $\mathrm{CO}_{2}$ efflux from soil and review of partitioning methods," Soil Biology and Biochemistry, vol. 38, no. 3, pp. 425-448, 2006.

[6] Å. Kasimir-Klemedtsson, L. Klemedtsson, K. Berglund, P. Martikainen, J. Silvola, and O. Oenema, "Greenhouse gas emissions from farmed organic soils: a review," Soil Use and Management, vol. 13, no. 4, pp. 245-250, 1997.

[7] Ö. Berglund and K. Berglund, "Influence of water table level and soil properties on emissions of greenhouse gases from cultivated peat soil," Soil Biology and Biochemistry, vol. 43, no. 5, pp. 923-931, 2011.

[8] J. Jauhiainen, A. Hooijer, and S. E. Page, "Carbon dioxide emissions from an Acacia plantation on peatland in Sumatra, Indonesia," Biogeosciences, vol. 9, no. 2, pp. 617-630, 2012.

[9] Ö. Berglund, K. Berglund, and L. Klemedtsson, "A lysimeter study on the effect of temperature on $\mathrm{CO}_{2}$ emission from cultivated peat soils," Geoderma, vol. 154, no. 3-4, pp. 211-218, 2010. 
[10] A. Hadi, K. Inubushi, Y. Furukawa, E. Purnomo, M. Rasmadi, and H. Tsuruta, "Greenhouse gas emissions from tropical peatlands of Kalimantan, Indonesia," Nutrient Cycling in Agroecosystems, vol. 71, no. 1, pp. 73-80, 2005.

[11] A. B. Ismail, "Farm management practices for mitigation of carbon dioxide emission in peatland agrosystems," in Proceedings of the International Conference on Balanced Nutrient Management for Tropical Agriculture, pp. 72-76, Pahang, Malaysia, August 2010.

[12] C. Kechavarzi, Q. Dawson, M. Bartlett, and P. B. LeedsHarrison, "The role of soil moisture, temperature and nutrient amendment on $\mathrm{CO}_{2}$ efflux from agricultural peat soil microcosms," Geoderma, vol. 154, no. 3-4, pp. 203-210, 2010.

[13] N. Fenner, N. J. Ostle, N. McNamara et al., "Elevated $\mathrm{CO}_{2}$ effects on peatland plant community carbon dynamics and DOC production," Ecosystems, vol. 10, no. 4, pp. 635-647, 2007.

[14] H. Vasander and J. Jauhiainen, "Land use change in tropical peatlands and current uncertainties in greenhouse gas emissions," in Proceedings of the International Symposium and Workshop on Tropical Peatland: Peatland Development-Wise Use and Impact Management, pp. 143-148, Sarawak, Malaysia, August 2008.

[15] A. B. Ismail, "Towards wise use of tropical peatland: from agriculture perspective," in Proceedings of the International Symposium and Workshop on Tropical Peatland, pp. 129-141, Sarawak, Malaysia, August 2008.

[16] M. L. Raziah and A. R. Alam, "Status and impact of pineapple technology on mineral soil," Economic and Technology Management Review, vol. 5, pp. 11-19, 2010.

[17] K. Inubushi, Y. Furukawa, A. Hadi, E. Purnomo, and H. Tsuruta, "Seasonal changes of $\mathrm{CO}_{2}, \mathrm{CH}_{4}$ and $\mathrm{N}_{2} \mathrm{O}$ fluxes in relation to land-use change in tropical peatlands located in coastal area of South Kalimantan," Chemosphere, vol. 52, no. 3, pp. 603-608, 2003.

[18] S. E. Page, C. J. Rieley, and J. O. Rieley, “Tropical peatlands: distribution, extent and carbon storage-uncertainties and knowledge gaps," in Proceedings of the International Symposium and Workshop on Tropical Peatland, Yogyakarta, Indonesia, August 2007.

[19] O. H. Ahmed, M. H. Ahmad Husni, A. B. Anuar, and M. M. Hanafi, Sustainable Production of Pineapples on Tropical Peat Soils, Universiti Putra Malaysia Press, Selangor, Malaysia, 2013.

[20] A. B. Ismail, J. Asing, and M. Zulkefli, "Residual impact of various land clearing techniques on peat chemical characteristics," in A Case Study at MARDI Peat Research Station Sessang, Sarawak, Malaysia, A. B. Ismail, H. K. Ong, M. J. Mohamad Hanif, and M. S. Umi Kalsom, Eds., pp. 33-61, MARDI, Sarawak, Malaysia, 2007.

[21] J. M. Bremner and D. R. Keeney, "Determination and isotoperatio analysis of different forms of nitrogen in soils. Part 3. Exchangeable ammonium, nitrate and nitrite by extraction-distillation method," Soil Science Society of America Journal, vol. 35, no. 5, pp. 577-582, 1966.

[22] D. W. Nelson and L. E. Sommers, "Total carbon, organic carbon and organic matter," in Methods of Soil Analysis, Chemical and Microbiological Properties, Part 2, A. L. Page, R. H. Miller, and D.R. Keeney, Eds., pp. 570-571, Soil Science Society of America, Wisconsin, Wis, USA, 1982.

[23] J. M. Bremner, "Nitrogen-total," in Methods of Soil Analysis, Part 3: Chemical Methods, D. L. Sparks, A. L. Page, P. A. Helmke et al., Eds., pp. 1085-1121, Soil Science Society of America, Madison, Wis, USA, 1960.
[24] Y. Harada and A. Inoko, "The measurement of the cationexchange capacity of composts for the estimation of the degree of maturity," Soil Science and Plant Nutrition, vol. 26, no. 1, pp. 127-134, 1980.

[25] E. T. Lim, "Physical analysis: determination of bulk density," in Peat Soils of Sarawak and the Analytical Methods, pp. 27-28, Department of Agriculture, Sarawak, Malaysia, 1991.

[26] E. Dugan, A. Verhoef, S. Robinson, and S. Saran, "Bio-char from sawdust, maize stover and charcoal: impact on water holding capacities (WHC) of three soils from Ghana," in Proceedings of the 19th World Congress of Soil Science: Soil Solutions for a Changing World, pp. 9-12, Brisbane, Australia, August 2010.

[27] M. Suhaimi, K. R. Emmyrafedziawati, M. S. Umi Kalsom, A. M. Sahilah, and A. B. Ismail, "Effect of land-clearing methods on distribution of microbial populations in peat ecosystem," in $A$ Case Study at MARDI Peat Research Station Sessang, Sarawak, Malaysia, A. B. Ismail, H. K. Ong, M. J. Mohamad Hanif, and M. S. Umi Kalsom, Eds., pp. 81-87, MARDI, Selangor, Malaysia, 2007.

[28] IAEA, "Sampling techniques and sample handling," in Manual on Measurement of Methane and Nitrous Oxide Emissions from Agriculture, IAEA-TECDOC, pp. 45-67, IAEA, Vienna, Austria, 1992.

[29] M. Zulkefli, L. K. C. Liza Nuriati, and A. B. Ismail, "Soil $\mathrm{CO}_{2}$ flux from tropical peatland under different land clearing techniques," Journal of Tropical Agriculture and Food Science, vol. 38, no. 1, pp. 131-137, 2010.

[30] B. Widén and A. Lindroth, "A calibration system for soil carbon dioxide-efflux measurement chambers: description and application," Soil Science Society of America Journal, vol. 67, no. 1, pp. 327-334, 2003.

[31] J. P. Andriesse, "The main characteristics of tropical peats," in Nature and Management of Tropical Peat Soils, FAO Soils Bulletin 59, FAO, Rome, Italy, 1988.

[32] M. Murtedza, E. Padmanabhan, B. L. H. Mei, and W. B. Siong, "The peat soils of Sarawak," Strapeat Status Report, 2002.

[33] MARDI, Master Plan for Malaysian Agricultural Research and Development Institute Sessang Peat Research Station, MARDI, Selangor, Malaysia, 1996.

[34] STRAPEAT-UNIMAS-NREB, "Physico-chemical characteristics," in Handbook for Environmental Impact Assessment (EIA) of Development on Peatlands, pp. 3-7, UNIMAS, Sarawak, Malaysia, 2004.

[35] M. M. Selamat, "Biologi tanaman dan keperluan persekitaran," in Penanaman Nanas-Nanas Makan Segar dan Nanas Kaleng, M. M. Selamat, Ed., pp. 7-16, MARDI, Selangor, Malaysia, 1996.

[36] P. Mäkiranta, K. Minkkinen, J. Hytönen, and J. Laine, "Factors causing temporal and spatial variation in heterotrophic and rhizospheric components of soil respiration in afforested organic soil croplands in Finland," Soil Biology and Biochemistry, vol. 40, no. 7, pp. 1592-1600, 2008.

[37] J. Paz-Ferreiro, E. Medina-Roldán, N. J. Ostle, N. P. McNamara, and R. D. Bardgett, "Grazing increases the temperature sensitivity of soil organic matter decomposition in a temperate grassland," Environmental Research Letters, vol. 7, Article ID 014027, pp. 1-5, 2012.

[38] H. E. Dickens and J. M. Anderson, "Manipulation of soil microbial community structure in bog and forest soils using chloroform fumigation," Soil Biology and Biochemistry, vol. 31, no. 14, pp. 2049-2058, 1999. 
[39] S. Hu and A. H. C. Van Bruggen, "Efficiencies of chloroform fumigation in soil: effects of physiological states of bacteria," Soil Biology and Biochemistry, vol. 30, no. 13, pp. 1841-1844, 1998.

[40] K. Toyota, K. Ritz, and I. M. Young, "Survival of bacterial and fungal populations following chloroform-fumigation: effects of soil matric potential and bulk density," Soil Biology and Biochemistry, vol. 28, no. 10-11, pp. 1545-1547, 1996.

[41] E. R. Ingham and K. A. Horton, "Bacterial, fungal and protozoan responses to chloroform fumigation in stored soil," Soil Biology and Biochemistry, vol. 19, no. 5, pp. 545-550, 1987.

[42] D. S. Jenkinson and D. S. Powlson, "The effects of biocidal treatments on metabolism in soil-I. Fumigation with chloroform," Soil Biology and Biochemistry, vol. 8, no. 3, pp. 167-177, 1976.

[43] L. Zelles, A. Palojärvi, E. Kandeler, M. Von Lützow, K. Winter, and Q. Y. Bai, "Changes in soil microbial properties and phospholipid fatty acid fractions after chloroform fumigation," Soil Biology and Biochemistry, vol. 29, no. 9-10, pp. 1325-1336, 1997.

[44] S. Saggar, N. Jha, J. Deslippe et al., "Denitrification and $\mathrm{N}_{2} \mathrm{O}: \mathrm{N}_{2}$ production in temperate grasslands: processes, measurements, modelling and mitigating negative impacts," Science of the Total Environment, vol. 465, pp. 173-195, 2013.

[45] A. R. Yallop and B. Clutterbuck, "Land management as a factor controlling dissolved organic carbon release from upland peat soils 1: spatial variation in DOC productivity," Science of the Total Environment, vol. 407, no. 12, pp. 3803-3813, 2009.

[46] F. Worrall, H. S. Gibson, and T. P. Burt, "Modelling the impact of drainage and drain-blocking on dissolved organic carbon release from peatlands," Journal of Hydrology, vol. 338, no. 1-2, pp. 15-27, 2007. 

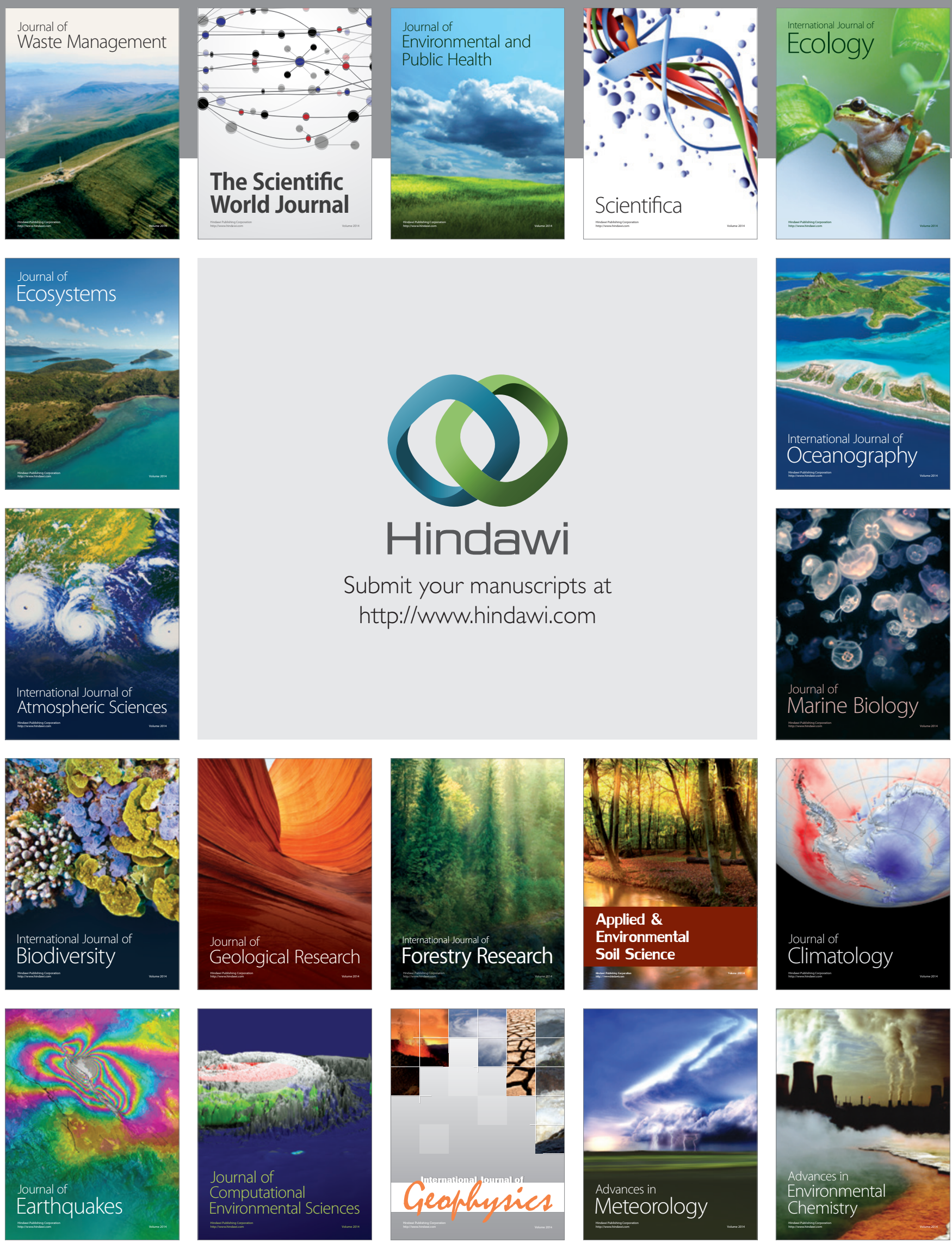